\title{
ANALISIS VALUE CHAIN DAN MARGIN PEMASARAN RANTAI PASOK TANDAN BUAH SEGAR SAWIT RAKYAT DI KABUPATEN BENGKALIS
}

\author{
Analysis of The Value Chain and Marketing Margins of \\ Palm Fresh Fruit Bunches Supply Chain in Bengkalis District
}

\author{
Nur Fitri Rahayu*, Hartrisari Hardjomidjojo, Sapta Raharja \\ Program Studi Teknik Industri Pertanian - Fakultas Teknologi Pertanian - \\ Institut Pertanian Bogor \\ Jl. Raya Dramaga - Bogor 16680 \\ *Penulis Korespondensi, email: nur_fitri@apps.ipb.ac.id
}

Disubmit : 20 Januari $2021 \quad$ Direvisi : 07 Mei $2021 \quad$ Diterima : 16 Juli 2021

\begin{abstract}
ABSTRAK
Usaha perkebunan kelapa sawit di Kabupaten Bengkalis didominasi oleh usaha perkebunan rakyat yang memiliki produk utama berupa Tandan Buah Segar (TBS). Jumlah produksi TBS tersebut sangat tinggi, namun pengelolaan rantai pasok TBS dirasakan masih kurang efisien sehingga pendapatan petani rendah. Hal ini dikarenakan jaringan distribusi komoditi sangat panjang serta fluktuasi harga pada saat distribusi TBS. Penelitian ini bertujuan untuk memetakan rantai nilai kelapa sawit di Kabupaten Bengkalis dan menganalisis margin pemasaran yang diperoleh petani. Data yang digunakan pada penelitian ini adalah data primer dan sekunder. Pengumpulan data primer dilakukan dengan observasi dan wawancara dengan petani dan anggota rantai pasok, sedangkan data sekunder diperoleh dari Dinas Perkebunan Bengkalis. Analisis data dilakukan dengan menggunakan pemetaan value chain dan margin pemasaran. Hasil penelitian menunjukkan bahwa terdapat empat jaringan rantai pasok TBS sawit rakyat di Kabupaten Bengkalis, yaitu jaringan I (petani-pengumpul-pedagang besar sawit-industri), jaringan II (petani-pedagang besar sawit-industri), jaringan III (petani-pengumpul-koperasiindustri) dan jaringan IV (petani-koperasi sawit-industri). Dari empat jaringan distribusi tersebut, jaringan IV di Kecamatan Pinggir yang paling banyak memperoleh nilai farmer's share sebesar $78,21 \%$. Sementara, nilai terkecil diperoleh pada jaringan I di Kecamatan Bantan sebesar 46,43\%
\end{abstract}

Kata kunci: Kelapa Sawit; Margin Pemasaran; Rantai Pasok; Value Chain

\section{ABSTRACT}

The business of palm oil plantation in the Bengkalis Regency is dominated by smallholder which has Fresh Fruit Bunches (FFB) as the main product. The total production of it grows annually, however, the long of supply chain of FFB is still inefficient so the revenue of the farmer is low. This is due to the long distribution network of the product and price fluctuation at distribution time. This study aimed to map value chain of the palm oil in Bengkalis and to analyze its marketing margin obtained by the farmers. Data used in this study were primary dan secondary data. Primary data colletction was carried out by observation and interviews with farmers and supply chain members, while secondary data was obtained from the Bengkalis Plantation Agency. Moreover, the data were analyzed by using value chain and marketing margin methods. The result of this study indicated that there are four palm oil distribution networks in Bengkalis, networks (N): N1 (farmer-collector-trader-industry), N2 (farmer-traderindustry), N3 (farmer-collector-cooperative-industry), and N4 (farmer-cooperative-industry). Based on the four distribution networks, the N4 network in Pinggir District received the most farmer's share of $78.21 \%$. Meanwhile, the smallest value was obtained in N1 in Bantan District of $46.43 \%$

Keywords: Food Supply Chain Network, Palm oil, Supply chain 


\section{PENDAHULUAN}

Kelapa sawit adalah komoditas yang berkembang pesat dari tahun ke tahun serta komoditas yang banyak diusahakan oleh masyarakat Indonesia, khususnya masyarakat Provinsi Riau (Syahza, 2011). Komoditas kelapa sawit berpotensi dalam peningkatan perekonomian masyarakat setempat dan prospek yang cukup besar dalam meningkatkan taraf hidup petani. Sentra produksi sawit terluas adalah Provinsi Riau, dengan total luas lahan mencapai 2489957 Ha pada tahun 2018 (BPS Riau, 2020). Lahan-lahan tersebut tersebar pada beberapa wilayah, salah satunya adalah Kabupaten Bengkalis. Berdasarkan data BPS Riau (2020), luas lahan sawit di Provinsi Riau pada tahun 2018 berturut-turut, yaitu Kampar 413.590 Ha, Rokan Hulu 410.306 Ha, Siak 347.058 $\mathrm{Ha}$, Pelalawan $325.241 \mathrm{Ha}$, Rokan Hilir 282.289 Ha, Indragiri Hilir 227.802 Ha, Bengkalis $186.724 \mathrm{Ha}$, Kuantan Singingi $128.699 \mathrm{Ha}$, Indragiri Hulu $118.969 \mathrm{Ha}$, Kota Dumai 38.350 Ha dan Kota Pekanbaru 10.929 Ha. Data tersebut menunjukkan bahwa Kabupaten Bengkalis merupakan sentra terbesar ke-7 di Provinsi Riau dan memiliki potensi perkembangan kelapa sawit (BPS Riau, 2020). Mayoritas mata pencaharian masyarakat Kabupaten Bengkalis adalah dengan berkebun kelapa sawit.

Usaha perkebunan kelapa sawit dilakukan oleh masyarakat yang disebut Perkebunan Rakyat (PR) dan Perkebunan Besar Swasta (PBS). Total produksi Tandan Buah Segar (TBS) dari perkebunan Rakyat Bengkalis pada tahun 2019 sekitar 1.215.436,10 ton (BPS Kabupaten Bengkalis, 2020). Ramadhansyah (2017) menyebutkan bahwa petani mandiri atau petani rakyat adalah petani yang sejak awal mengusahakan dan mengelola kebunnya secara mandiri. Namun, lebih lanjut Pratama (2020) menjelaskan bahwa dalam pengolahan hasil panen TBS, petani membutuhkan bantuan dari Pabrik Pengolahan Kelapa Sawit (PPKS) untuk diolah menjadi Crude Palm Oil (CPO). Dana yang dikeluarkan dalam proses awal penanaman, pemeliharaan, pemanenan, sampai mendistribusikan ke anggota rantai pasok lainnya merupakan dana milik sendiri. Harga CPO di dalam negeri sangat ditentukan oleh keadaan harga di bursa berjangka Kuala Lumpur dan Rotterdam. Terjadinya fluktuasi harga Minyak Kelapa Sawit (MKS) disebabkan oleh goncangan pasokan (Supply Shock) dimana harga CPO merupakan acuan utama untuk menetapkan harga TBS (Pratama, 2020). Lebih lanjut, Mulyana (2008) menyebutkan bahwa munculnya kebijakan pemerintah yang menentukan harga TBS berdasarkan harga ekspor atau Free on Board (FOB) minyak kelapa sawit.

Produksi TBS dari petani dijual ke pabrik sawit yang ada di daerah setempat, namun melalui beberapa jaringan distribusi. Mayoritas petani rakyat di Kabupaten Bengkalis menjual hasil panen ke pedagang pengumpul dan pedagang besar sawit. Kondisi tersebut menyebabkan kerentanan terjadinya fluktuasi harga, yang dipengaruhi oleh panjangnya mata rantai pasok dan ketersediaan pasokan TBS. Selain itu, lemahnya informasi mengenai harga TBS yang diperoleh, petani sawit cenderung hanya mengandalkan informasi yang diterima dari pedagang perantara. Da Silva et al. (2009) dan Pratama et al. (2018) menyebutkan bahwa produsen dan pembeli akhir dari rantai nilai, biasanya ingin memotong jalur distribusi pedagang perantara dan menginginkan pasar yang lebih kompetitif. Hal ini bertujuan agar kedua aktor rantai pasok tersebut dapat memperoleh nilai dan jaminan produk berkualitas ditingkat kosumen akhir. Kondisi harga TBS yang semakin merosot membuat banyak petani sawit membiarkan kebun sawit terbengkalai dan beralih ke usaha lain untuk memenuhi kebutuhan sehari-hari (Pratama, 2020).

Kondisi rantai pasok TBS di Kabupaten Bengkalis masih belum berjalan dengan baik. Masalah tersebut disebabkan karena pengukuran kinerja rantai pasok masih belum optimal, dimana antara jaringan distribusi masih memiliki nilai margin pemasaran besar namun nilai farmer's share masih rendah. Hasil survei dengan petani di lapangan, saat ini harga TBS hanya Rp 510 sampai Rp 1.040,8/kg ditingkat petani, sedangkan harga minyak kelapa sawit ditetapkan Rp 6.465,05/ kg. 
Terkait hal tersebut terdapat suatu indikasi permasalahan yang membuat margin keuntungan dalam penjualan TBS tidak terdistribusi dengan baik. Menurut Pratama (2020), margin yang cukup besar membuat petani sawit khususnya petani rakyat semakin sengsara dan apabila petani ingin mendapatkan keuntungan yang sesuai maka petani harus memutus rantai pemasaran. Pemutusan salah satu mata rantai seperti pemasaran ke tengkulak atau petani menjual hasil panen langsung ke pabrik maka diharapkan petani akan mendapatkan keuntungan lebih besar.

Terkait dengan hal di atas, dilakukan penelitian mengenai pemetaan rantai nilai. Tahapan pertama dalam penelitian ini adalah melakukan pemetaan rantai nilai TBS yang ada di Bengkalis. Hasil dari pemetaan rantai nilai jaringan distribusi selanjutnya dihitung nilai margin pada petani sawit pasokan distribusi TBS. Tujuannya untuk melihat berapa keuntungan yang diperoleh petani TBS tersebut.

\section{METODE}

\section{Metode Pengumpulan Data}

Penelitian ini dilakukan di Kabupaten Bengkalis Provinsi Riau, tepatnya di Kecamatan Bengkalis, Kecamatan Mandau, Kecamatan Bantan, dan Kecamatan Pinggir. Pemilihan lokasi tersebut dilakukan secara sengaja (purposive) terhadap petani kelapa sawit rakyat di Kabupaten Bengkalis. Data yang digunakan adalah data primer dan sekunder. Metode pengumpulan data primer yang digunakan adalah metode observasi lapangan dengan wawancara mendalam kepada petani sawit, pedagang pengumpul (tengkulak), dan pedagang besar sawit. Pelaksanaan pengumpulan data penelitian dimulai dari bulan Juni hingga Juli tahun 2019. Penentuan sampel petani ditentukan secara sengaja (purposive), dengan kriteria, yaitu: memiliki tanaman sawit yang diambil minimal berumur 5 tahun, dengan luas lahan minimal 1,5 $\mathrm{Ha}$, dan memiliki aliran distribusi tanaman sawit yang panjang serta kurangnya masalah informasi dan pengetahuan petani untuk aliran kelapa sawit. Sampel anggota distribusi yang terlibat dalam distribusi TBS sampai kepada konsumen (pabrik) ditentukan dengan metode snowball sampling, yaitu penentuan sampel anggota distribusi yang mula-mula berdasarkan informasi dari petani responden, berikutnya berdasarkan anggota distribusi yang ditunjuk oleh petani responden, dan seterusnya sampai ke konsumen. Data sekunder diperoleh dari Badan Pusat Statistik dan Dinas Perkebunan Kabupaten Bengkalis.

\section{Analisis Rantai Nilai (ARN)}

Rantai nilai merupakan aktivitas dalam sebuah sistem dengan adanya perubahan input menjadi output (Kusumawati, 2013). Aktivitas dalam rantai nilai yang berbeda dan spesifik adalah unit dasar yang dapat digunakan untuk memahami keunggulan kompetitif karena setiap aktor adalah pengendara dari biaya relatif perusahaan dan tingkat diferensi perusahaan yang dapat diberikan kepada konsumen (Rothaermel, 2017). Pemetaan rantai nilai dapat dipetakan menggunakan analisis rantai nilai yang merupakan alat bantu untuk pendekatan kualitatif atau kuantitatif (Pratama et al., 2018).

\section{Analisis Margin Pemasaran}

Margin pemasaran adalah selisih harga yang dibayar ke petani dengan harga yang dibayar oleh konsumen (Jumiati et al., 2013; Mumbeya, 2011). Menurut Phiri et al. (2013), rumus menghitung margin pemasaran seperti pada Persamaan (1).

$\mathrm{MP}=\mathrm{HJ}-\mathrm{HP}$

Keterangan:

MP : Margin pemasaran $(\mathrm{Rp} / \mathrm{kg})$

$\mathrm{HJ} \quad$ : Hargajual komoditas/produk $(\mathrm{Rp} / \mathrm{kg})$

HP : Harga pembeliankomoditas (Rp/kg)

Besarnya bagian yang diterima petani diestimasi dengan menggunakan rumus pada Persamaan (2) (Limbong dan Sitorus, 1987; Primalasari et al., 2017). 
Jurnal Teknologi Pertanian Vol. 22 No. 2 [Agustus 2021] 109-120

Analisis Value Chain dan Margin Pemasaran Rantai Pasok Tandan Buah Segar Sawit [Rahayu dkk]

$\mathrm{FS}=\frac{H P}{H K} \mathrm{X} 100 \%$

Keterangan:

FS :Farmer's share

$\mathrm{HP}:$ Harga ditingkat petani(rupiah $/ \mathrm{kg})$

HK :Harga di tingkat perusahaan (rupiah/kg)

\section{HASIL DAN PEMBAHASAN}

Struktur Jaringan Distribusi Kelapa Sawit Rakyat di Kabupaten Bengkalis

Struktur jaringan distribusi menggambarkan aliran Tandan Buah Segar (TBS) dari perkebunan kelapa sawit rakyat didistribusikan sampai ke pabrik sawit dengan melalui beberapa jaringan distribusi. Jenis jaringan distribusi menurut Kotler (2002) dapat diklasifikasikan sebagai berikut:

1. Jaringan langsung merupakan jaringan distribusi yang paling sederhana, yaitu jaringan dari produsen ke konsumen akhir tanpa perantara yang disebut jaringan nol tingkat (zero stage chanel).

2. Jaringan satu tingkat (one stage chanel) merupakan jaringan distribusi yang menggunakan satu perantara, yaitu melibatkan produsen dan pengecer.

3. Jaringan distribusi yang menggunakan dua kelompok pedagang besar dan pengecer. Jaringan distribusi ini disebut dengan jaringan distribusi dua tingkat (two stage chanel) dan jaringan ini merupakan jaringan yang banyak digunakan oleh produsen.

4. Jaringan distribusi tiga tingkat (three stage chanel) yang menggunakan tiga pedagang perantara dimana produsen memilih agen sebagai perantara untuk mendistribusikan barangnya kepada pedagang besar.

Struktur jaringan distribusi melibatkan beberapa anggota rantai pasok yang mempunyai fungsi yang berbeda. Rantai pasok kelapa sawit rakyat di Kabupaten Bengkalis memiliki kompleksitas anggota yang terlibat, diantaranya adalah petani, pedagang pengumpul kelapa sawit, pedagang besar sawit, koperasi sawit dan pabrik sawit. Struktur jaringan sawit rakyat yang ada di Kabupaten Bengkalis, diantaranya adalah:

- Jaringan I : Petani-pedagang pengumpul-pedagang besar-pabrik sawit

- Jaringan II : Petani-pedagang besar pabrik sawit

- Jaringan III : Petani-pedagang pengumpul koperasipabrik sawit

- Jaringan IV : Petani-pedagang pengumpul pabrik sawit

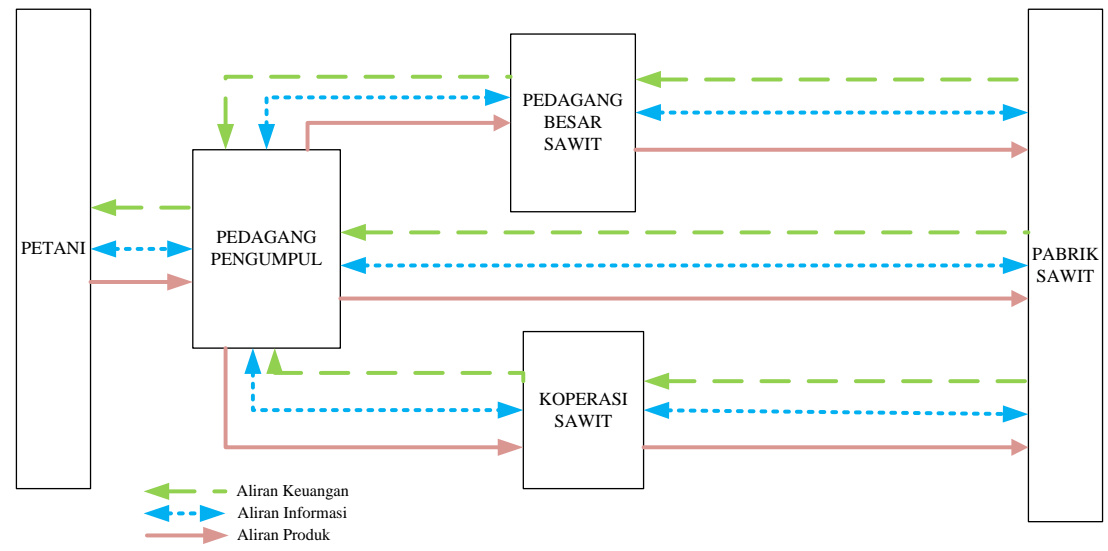

Gambar 1. Struktur rantai pasok kelapa sawit rakyat di kabupaten Bengkalis

Gambar 1 menjelaskan struktur rantai pasok yang menggambarkan pola aliran rantai pasok kelapa sawit rakyat secara umum dari petani hingga ke pabrik sawit. Pola aliran rantai pasok kelapa sawit rakyat di Kabupaten Bengkalis terbagi 
menjadi tiga, yaitu aliran produk, aliran informasi dan aliran uang. Berikut adalah penjelasan dari tiga pola aliran di setiap jaringan distribusi kelapa sawit rakyat di Kabupaten Bengkalis.

\section{Aliran Produk pada Jaringan Distribusi Kelapa Sawit}

Aliran produk mengalir dari hulu (upstream) ke hilir (downstrem) (Leppe dan Karuntu, 2019; Yuniar, 2012). Produk yang didistribusikan berupa TBS yang melewati beberapa jaringan distribusi. Aliran TBS dipanen dari petani dan mulai dikumpulkan untuk didistribusikan ke pedagang pengumpul. Pedagang pengumpul mendistribusikan TBS ke pedagang besar sawit menggunakan transportasi darat, sedangkan untuk pedagang pengumpul Kecamatan Bantan dan Kecamatan Bengkalis yang langsung mendistribusikan TBS ke pabrik mitra menggunakan transportasi darat dan melewati transportasi laut dengan penyebrangan kapal roll-on/roll-off (RoRo) di Bengkalis. Sesampainya di penyeberangan Pakning TBS langsung didistribusikan ke pabrik.

\section{Aliran Informasi pada Jaringan Distribusi Kelapa Sawit}

Aliran informasi pada rantai pasok kelapa sawit rakyat di Kabupaten Bengkalis berlangsung secara timbal balik mulai dari petani sampai ke pabrik sawit dan sebaliknya. Aliran informasi berbeda dengan aliran produk dan keuangan yang bersifat satu arah. Saragih (2016) menyatakan bahwa aliran informasi yang transparan dan memiliki instensitas baik dapat membangun kepercayaan diantara anggota rantai pasok yang bermitra. Di lapangan masih banyak ditemukan bahwa aliran informasi yang terjadi dalam jaringan distribusi TBS masih kurang transparan dan keterbatasan petani dalam menerima informasi terkait harga TBS yang sudah ditentukan. Hal ini, membuat petani rakyat menjual TBS dengan harga yang sudah ditentukan seadanya saja.

Informasi harga merupakan salah satu informasi yang penting dalam rantai pasok kelapa sawit rakyat. Harga TBS cenderung fluktuatif setiap hari membuat para anggota rantai pasok kelapa sawit harus terus mencari informasi terkait harga TBS untuk menghindari adanya kesalahan dalam menentukan harga jual maupun harga beli TBS (Pratama, 2020).

\section{Aliran Keuangan Pada Jaringan Distribusi Kelapa Sawit}

Aliran keuangan dalam rantai pasok kelapa sawit rakyat membahas terkait uang untuk pembayaran TBS yang dibeli dari anggota rantai pasok. Aliran keuangan dalam rantai pasok kelapa sawit yang diterima petani berupa uang. Aliran keuangan dari pabrik sawit ke koperasi dan pedagang besar pembayarannya bisa secara tunai dan kredit, yang keterkaitannya PBS langsung ke pabrik pembayaran secara kredit namun PBS yang tidak bermitra langsung ke pabrik tersebut bisa menerima pembayaran secara tunai dengan jangka waktu 7-10 hari kerja.

Sistem penjualan langsung TBS dari petani ke pengumpul dikarenakan petani membutuhkan uang tunai, adanya saling percaya antara petani dan pengumpul, dan sistem pembayaran ini sudah berlangsung lama. Petani yang menjual langsung ke pengumpul beralasan karena dengan sistem pembayaran secara tunai untuk dapat digunakan sebagai modal dan kebutuhan sehari-hari dan juga beralasan karena sudah terjalinnya hubungan yang baik antara petani dan pedagang pengumpul dalam waktu yang cukup lama. Pedagang pengumpul yang sudah terjalin dengan petani sawit ini juga memberikan pinjaman modal kepada petani, bisa berupa uang dan pupuk.

Aliran keuangan mengalir dari pabrik sawit hingga ke petani sawit. Pedagang pengumpul kelapa sawit membeli TBS di petani dan membayar langsung ke petani secara tunai. Petani Kabupaten Bengkalis memilih pola jaringan I, III, dan IV sebanyak 58\% dikarenakan petani yang menjual ke pengumpul kelapa sawit ini juga terkendala di transportasi yang kurang memadai dan juga hasil TBS yang di panen dalam sekala kecil. Jaringan II aktivitas keuangan berasal dari pedagang besar. Petani responden memilih jaringan II dikarenakan harga TBS lebih tinggi meskipun petani harus mengeluarkan 
biaya transportasi untuk pengiriman TBS ke pedagang besar yang jaraknya lebih jauh namun penjualan di jaringan II lebih menguntungkan dibandingkan ke jaringan I, III, dan IV. Sebagian pedagang besar langsung mengambil TBS di Tempat Pengumpulan Hasil (TPH) di perkebunan petani responden dengan harga beli lebih rendah dibandingkan petani langsung menjual TBS ke pedagang besar, hal ini disebabkan oleh pemotongan biaya angkut, biaya transportasi dan biaya penyusutan.

Adanya perbedaan jaringan dan panjang pendeknya jaringan distribusi ini akan mempengaruhi tingkat harga, bagian keuntungan dan uang yang diterima petani sawit. Namun, permasalahan yang sering terjadi dalam penjualan TBS ke anggota rantai pasok lainnya yaitu harga TBS yang berfluktuasi dan terkendala di transportasi yang kurang memadai dalam proses pengangkutan TBS ke jaringan distribusi lainnya seperti ke pengumpul, pedagang besar maupun ke koperasi sawit. Harga yang fluktuatif membuat petani cenderung mengalami kesengsaraan, apabila petani ingin mendapatkan harga yang lebih tinggi maka petani harus memutuskan mata rantai ke pedagang pengumpul dan menjual ke PBS atau langsung ke pabrik sawit (Pratama, 2020).

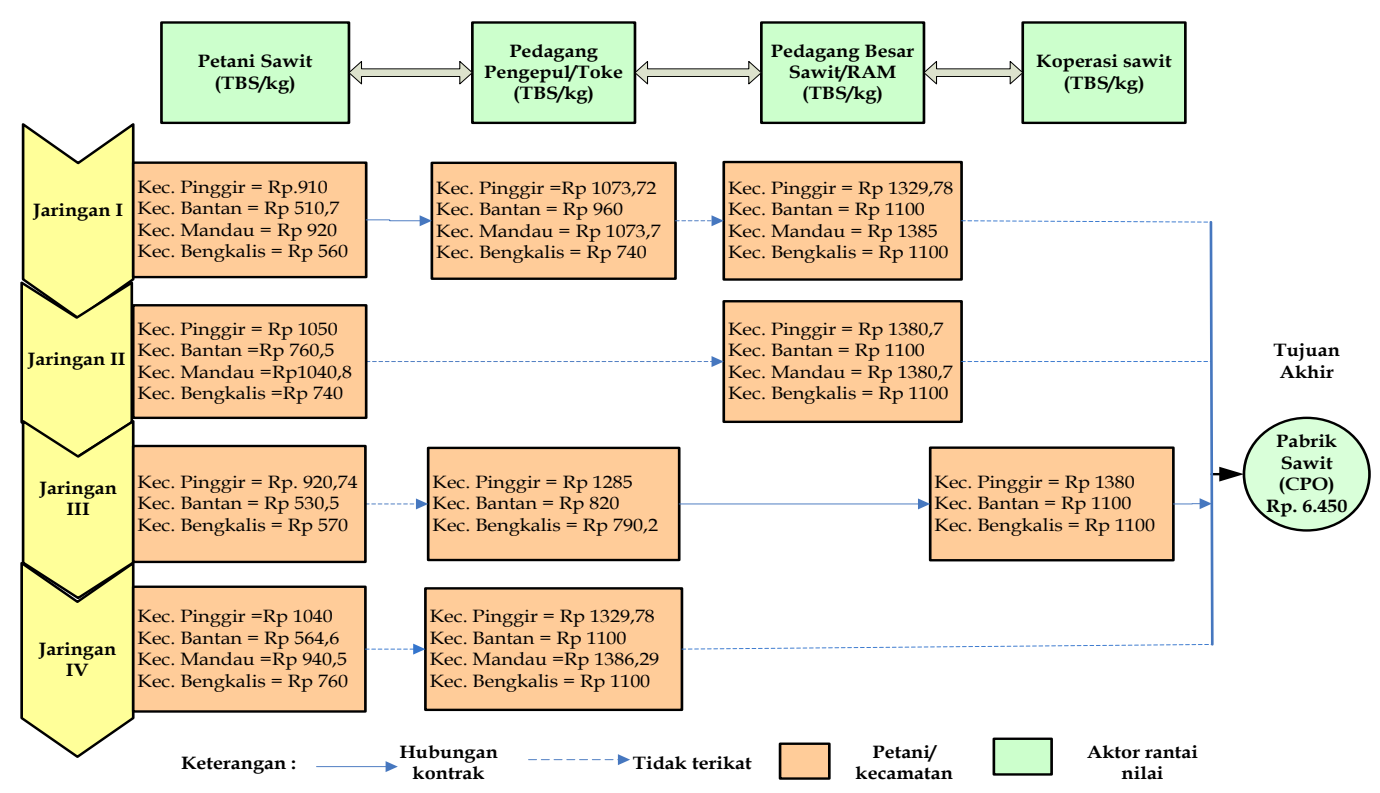

Gambar 2. Pemetaan rantai nilai kelapa sawit rakyat di Kabupaten Bengkalis Sumber: Olah data (2020)

\section{Analisis Rantai Nilai}

Rantai nilai adalah serangkaian aktivitas yang dibutuhkan untuk membuat dan menambahkan nilai pada suatu produk (Lie et al., 2012; Pratama et al., 2018). Organisasi rantai nilai merupakan sebuah hubungan manajemen atau sistem kerja yang terorganisir diantara anggota jaringan sepanjang rantai pasok, dalam organisasi rantai nilai keuntungan yang dicapai bukan hanya untuk sepihak namun dapat dirasakan pada semua pihak yang terkait dalam jaringan rantai pasok (Syibil, 2013). Rantai nilai berfungsi untuk memetakan hasil penelitian untuk masing-masing Kecamatan di setiap jaringan distribusi TBS kelapa sawit di Kabupaten Bengkalis.

Analisis rantai nilai kelapa sawit rakyat yang ada di Kabupaten Bengkalis di mulai dari petani mendistribusikan TBS ke pedagang pengumpul, pedagang besar sawit dan koperasi sampai ke tujuan akhir yaitu pabrik sawit yang ditunjukkan pada Gambar 2. Setiap aktivitas rantai nilai tersebut melibatkan sejumlah aktor yang ada di setiap jaringan distribusi TBS. Rantai nilai di dalam penelitian ini membahas terkait pemetaan dari kegiatan distribusi 
kelapa sawit dan penjelasan dari aktoraktor yang terlibat di dalam mendistribusikan TBS sampai ke pabrik sawit.

Pada rantai nilai TBS kelapa sawit di Kabupaten Bengkalis terdapat beberapa aktor mulai dari petani hingga ke konsumen akhir (PKS). Berikut fungsi dan pelaku aktor dalam rantai nilai TBS kelapa sawit.

\section{Petani}

Kelapa sawit merupakan tanaman yang berkontribusi dalam membantu perekonomian petani masyarakat Kabupaten Bengkalis. Tanaman kelapa sawit sebagai tanaman utama di masyarakat Bengkalis. Aktivitas petani sawit dimulai dengan pembersihan lahan, penanaman pohon sawit menggunakan bibit yang unggul dengan jarak tanam per pohon sekitar 9-10 m dalam satu hektar dan bisa menanam sekitar 125-135 pohon sawit. Perawatan seperti pemangkasan daun, pembersihan rumput disekitar pohon, pemberian pupuk di lakukan selama 2-3 kali/tahun. Kegiatan petani yang selanjutnya yaitu pemanenan buah. Panen adalah kegiatan untuk memotong TBS yang sudah matang dari pohon. Pada penelitian Yulistriani et al. (2018), menyebutkan bahwa standar buah panen kelapa sawit yang diaplikasikan oleh petani adalah pada saat buah kelapa sawit telah jatuh dari tandannya sebanyak 5 butir dan berdasarkan kearifan lokal atau berdasarkan standar yang dibuat oleh petani dengan toke/tengkulak. Sebanyak $20 \%$ petani melakukan panen hingga 4 kali dalam satu bulan pada musim hujan dan 3 kali dalam satu bulan pada musim kemarau selebihnya melakukan panen 2 kali dalam sebulan. Hasil penelitian di lapangan sebagian besar petani melaukan pemanenan sebanyak 2 kali dalam 1 bulan. Hal tersebut dikarenakan menunggu persiapan panen dan untuk mengurangi biaya panen. Menurut Dianto et al. (2017) dan Tansala et al. (2017), persiapan pemanenan yang baik akan menjamin tercapainya target produksi dengan biaya panen seminimal mungkin.

Petani langsung mendistribusikan ke pedagang sawit setelah pemanenan TBS dilakukan. Hasil panen dijual ke pedagang melalui beberapa jaringan distribusi, ada yang mendistribusikan ke pedagang pengumpul, langsung ke PBS, dan ada juga ke koperasi sawit. Namun saat penelitian di lokasi sampel yang diteliti tidak ada petani responden yang mendistribusi TBS langsung ke pabrik sawit, hal ini dikarenakan kapasitas hasil panen tidak besar dan kurang memadainya alat transportasi. Jumlah sampel petani responden yang diwawancara sebanyak 100 orang yang terbagi dari empat Kecamatan, dimana Kecamatan Pinggir sebanyak 30 orang, Kecamatan Bantan 14 orang, Kecamatan Mandau sebanyak 35 orang, dan terakhir Kecamatan Bengkalis sebanyak 21 orang.

Pada saat penelitian harga TBS yang diterima petani bervariasi dari harga $\mathrm{Rp} 510$ sampai Rp 1.040,8/kg ditingkat petani, sedangkan harga minyak kelapa sawit ditetapkan Rp 6.465,05/kg. Harga TBS yang didistribusi ke pedagang pengumpul lebih murah dibandingkan langsung mendistribusikan langsung ke pedagang besar atau koperasi sawit. Harga untuk mendistribusi ke pedagang pengumpul Rp 510 harga terendah berada di Kecamatan Bantan, sedangkan untuk harga Rp 1.040,8 diperoleh petani responden yang berada di lokasi Kecamatan Mandau dan Pinggir. Petani sawit dari daerah Kecamatan Mandau dan Kecamatan Pinggir mayoritas menjual hasil panen mereka ke PBS terdekat dari perkebunan yang mereka kelola dimana harga sawit lebih tinggi dibandingkan dengan menjual ke pengumpul terdekat. Namun ada juga sebagian petani menjual ke pengumpul kelapa sawit karena mempertimbangkan transportasi yang tidak memadai. Menurut (Ugroseno dan Wachjar, 2017) transportasi menjadi hal yang penting dalam menyalurkan hasil panen dari tempat penampungan hasil hingga menuju loading ramp di pabrik kelapa sawit dan kebutuhan transportasi dalam mengangkut TBS perlu diperhatikan agar mempercepat pengangkutan TBS ke pabrik.

\section{Pedagang Pengumpul/Tengkulak/Toke}

Pedagang pengumpul merupakan anggota yang melakukan pembelian hasil 
panen TBS dari petani. Aktivitas pedagang pengumpul dimulai dari pembeli TBS milik petani, ada yang langsung membeli ke lokasi perkebunan milik petani dan ada yang petani langsung menjual ke lokasi pedagang pengumpul. Hubungan pedagang pengumpul dengan petani responden memiliki ketergantungan dari segi ekonomi, juga disebabkan karena pedagang pengumpul dapat membantu menjualkan hasil panen dari petani. Petani responden yang memilih menjual ke pedagang pengumpul juga beralasan karena tidak memiliki akses untuk menjual hasil panen ke tingkat PBS atau koperasi karena terkendalanya modal, transportasi dan kapasitas hasil produksi tidak terlalu banyak. Kebutuhan ekonomi dan modal kerja yang terbatas menyebabkan petani responden mendistribusikan ke pedagang pengumpul meskipun harga yang peroleh lebih rendah dibandingkan mendistribusikan ke anggota lainnya.

Pedagang pengumpul biasanya membeli TBS dengan harga rendah karena pedagang pengumpul mendistribusikan lagi TBS ke tempat penampungan lebih besar seperti ke PBS, koperasi atau langsung ke pabrik sawit dan membutuhan biaya untuk transportasi serta upah pekerja. Pedagang pengumpul biasanya memutuskan mendistribusikan hasil beli TBS dari petani ke PBS atau koperasi sawit beralasan karena mereka sudah memiliki kontrak atau bermitra lama dengan pedagang pegumpul. Penetapan harga sudah ditentukan oleh pedagang pengumpul dengan harga yang sudah disepakati antara petani dengan pedagang. Hasil produksi TBS yang di panen dijual ke pedagang pengumpul bisa langsung memperoleh uang dari hasil penjualan TBS, bisa meminjam dana sewaktu-waktu dibutuhkan, serta lokasi dari perkebunan juga dekat. Sama halnya dengan hasil penelitian Noor (2013) yang menyatakan bahwa lebih banyak petani yang menjual langsung ke pedagang pengumpul karena petani akan langsung dibayar tunai oleh para pedagang pengumpul.

\section{Pedagang Besar Sawit (PBS)}

Pedagang besar adalah rantai tataniaga atau lembaga akan melakukan penyortiran dan membeli tandan buah segar (TBS) kelapa sawit yang akan dijual ke pabrik kelapa sawit (Novida et al., 2020). Aktivitas Pedagang Besar Sawit (PBS) hampir sama dengan pedagang pengumpul, namun PBS merupakan pedagang sawit yang skala kapasitas pembelian/penampungan lebih besar. PBS menjual TBS dari petani atau pedagang pengumpul langsung ke pabrik kelapa sawit.

\section{Koperasi Sawit}

Koperasi sawit merupakan lembaga yang tersedia untuk mengelola jual beli TBS dari petani yang kemudian didistribusikan ke pabrik. Tujuan koperasi tersebut untuk memberdayakan dalam usahapeningkatan kesejahteran ekonomi masyarakat. Koperasi sawit dibentuk untuk mengembangkan lagi perkebunan sawit rakyat ke skala lebih besar. Petani yang bermitra dengan koperasi berkewajiban menjual hasil produksi dari kebun sawit yang dikelolanya. Koperasi berkewajiban membeli produksi TBS dari petani yang sudah bermitra dengan harga yang sesuai pedoman yang sudah ditentukan oleh pemerintah.

\section{Pabrik Kelapa Sawit (PKS)}

Perusahaan perkebunan adalah suatu perusahaan berbentuk badan usaha atau badan hukum yang bergerak dalam kegiatan budidaya tanaman perkebunan diatas lahan yang dikuasi, dengan tujuan ekonomi atau pun komersial dan mendapat izin usaha dari instansi yang berwenang dalam pemberian izin usaha perkebunan (Gunanegara, 2019). Menurut BPS Indonesia (2020), perusahaan perkebunan didefinisikan sebagai pelaku usaha perkebunan warga negara Indonesia atau badan hukum yang didirikan menurut hukum Indonesia dan berkedudukan di Indonesia yang mengelola usaha perkebunan dengan skala tertentu. Pabrik sawit merupakan lokasi penjualan TBS terakhir dalam penelitian ini, dimana pabrik sawit berperan dalam mengolah TBS menjadi CPO. Pada penelitian ini, peneliti tidak dapat izin untuk melakukan penelitian lebih lanjut terkait jumlah TBS yang dibeli pabrik sawit. 


\section{Kinerja Rantai Pasok TBS Kelapa Sawit}

Pengukuran kinerja rantai pasok dilihat dari analisis efesiensi pemasaran yang mencerminkan efesiensi rantai pasok, yakni dari margin pemasaran dan farmer's share (Rasoki et al., 2017). Margin pemasaran adalah perbedaan harga yang dibayar ke petani dan harga yang dibayar oleh konsumen dan itu pada umumnya digunakan untuk mengukur kinerja sistem pemasaran (Mumbeya, 2011). Penelitian ini membahas mengenai perhitungan total nilai margin pemasaran pada bulan Juni 2019 setiap jaringan yang ada di keempat Kecamatan. Perhitungan total margin pemasaran untuk keempat Kecamatan dari masing-masing jaringan distribusi dapat dilihat pada Tabel 1.
Berdasarkan hasil rekapan perhitungan pada Tabel 1, diketahui bahwa harga ditingkat petani bervariasi tergantung mata rantai penjualan ke anggota lainnya. Kecamatan Bantan dan Bengkalis nilai margin pemasaran di Kecamatan Bantan dan Bengkalis tertinggi pada jaringan ke I dengan total nilai Rp 589 dan Rp 540, sedangkan nilai yang terendah pada jaringan ke 4 yaitu sebesar Rp 320 dan Rp 340. Perbedaan margin pemasaran yang terjadi disebabkan oleh harga TBS yang berfluktuasi. Harga TBS di kedua Kecamatan ini relatif rendah karena letak posisi pabrik berseberangan pulau harus menggunakan tranportasi penyebrangan laut untuk mendistribusikan TBS ke pabrik sehingga membutuhkan biaya pemasaran yang lebih besar.

Tabel 1. Rekapan nilai margin pemasaran dan farmer's share TBS Juni 2019

\begin{tabular}{lccccc}
\hline Kecamatan & Jaringan & HP (Rp) & HK (Rp) & FS (\%) & MP (Rp) \\
\hline \multirow{4}{*}{ Bantan } & I & 510,7 & 1.100 & 46,43 & 589 \\
& II & 760,5 & 1.100 & 69,14 & 340 \\
& III & 530,5 & 1.100 & 48,23 & 570 \\
& IV & & 1.100 & 70,95 & 320 \\
\hline \multirow{3}{*}{ Bengkalis } & I & 560 & 1.100 & 50,91 & 540,0 \\
& II & 740 & 1.100 & 67,27 & 360,0 \\
& III & 570 & 1.100 & 51,82 & 530,0 \\
& IV & 760 & 1.100 & 69,09 & 340,0 \\
\hline \multirow{3}{*}{ Mandau } & I & 920 & $1.386,29$ & 66,36 & 466,29 \\
& II & $1.040,8$ & $1.380,70$ & 75,38 & 339,90 \\
\hline \multirow{2}{*}{ Pinggir } & IV & 940,5 & 1.385 & 67,91 & 444,50 \\
& I & 910 & $1.329,78$ & 68,43 & 419,78 \\
& II & 1.050 & $1.380,70$ & 76,05 & 330,70 \\
& III & 920,74 & 1.380 & 66,72 & 459,26 \\
& IV & 1.040 & $1.329,78$ & 78,21 & 289,78 \\
\hline
\end{tabular}

Sumber: Olah data (2020)

Keterangan: HP: Harga Petani, HK: Harga Konsumen, FS: Farmer Share, MP: Margin Pemasaran

Kecamatan Pinggir dan Mandau harga ditingkat petani diperoleh lebih tinggi pada jaringan I yaitu sebesar $\mathrm{Rp} 466,29$ untuk Kecamatan Mandau, sedangkan untuk Kecamatan Pinggir margin tertinggi pada jaringan ke III yaitu sebesar Rp 459,26. Posisi perkebunan petani di kedua Kecamatan ini tidak sejauh Kecamatan Bantan dan Kecamatan Bengkalis dan juga dikarenakan terdapat beberapa pabrik sawit. Tinggi rendahnya suatu nilai margin tergantung dari biaya pemasaran TBS yang didistribusikan dari TPH hingga ke konsumen akhir.

Nilai farmer'share yang diperoleh petani dilihat dari tabel di atas terbanyak diperoleh di jaringan ke IV yaitu di Kecamatan Pinggir sebesar 78,21\% sedangkan nilai terendah di Kecamatan Bantan pada jaringan ke I yaitu 46,43\%. fluktuasi harga juga memberikan kesempatan kepada pedagang pengumpul untuk mengambil keuntungan yang lebih tinggi dengan cara memanipulasi informasi 
harga ditingkat petani. Apabila harga naik maka pedagang lambat memberitahukan kepada petani, sedangkan apabila harga turun informasi akan langsung disampaikan kepada petani dan petani akan ditekan dengan harga yang rendah.

Secara keselurahan dilihat dari hasil rekapan margin pemasaran dan farmer's share di atas dapat disimpulkan bahwa makin panjang mata rantai distribusi rantai pasok maka semakin rendah nilai farmer's share yang didapat petani. Farmer's share adalah selisih antara harga retail dan harga ditingkat petani. Hal tersebut digunakan untuk mengetahui porsi harga di tingkat konsumen yang diperoleh petani. Nilai farmer's share yang besar berarti porsi atau bagian yang dinikmati petani besar dan jaringan tata niaga tersebut efisien, sedangkan nilai yang kecil berarti porsi atau bagian yang dinikmati oleh petani kecil dan jaringan tataniaga tersebut tidak efisien (Lubis dan Tinaprilla, 2016). Jaringan distribusi yang lebih pendek perlu diupayakan untuk meningkatkan share harga yang diterima petani.

\section{SIMPULAN}

Simpulan dari penelitian ini adalah terdapat 4 alternatif jaringan distribusi rantai pasok TBS sawit rakyat di Kabupaten Bengkalis, diantaranya jaringan distribusi I merupakan jaringan TBS yang berasal dari petani rakyat, pengumpul kelapa sawit, pedagang besar, hingga ke pabrik sawit. Jaringan distribusi ke II yang melibatkan aktor petani rakyat, PBS dan pabrik kelapa sawit. Selanjutnya, jaringan distribusi III merupakan jaringan TBS yang berasal dari petani rakyat, pengumpul kelapa sawit, koperasi hingga ke pabrik sawit. Pola jaringan ke IV berasal dari petani rakyat mendistribusikan ke pengumpul kelapa sawit hingga ke pabrik sawit. Penelitian ini juga menghasilkan nilai margin pemasaran terbesar berada pada jaringan I yang ada di Kecamatan Bantan yaitu sebesar Rp 589/kg. Besarnya margin pemasaran pada jaringan I dikarenakan pedagang pengumpul membeli TBS dari petani dengan harga yang lebih rendah dari harga pabrik. Margin pemasaran yang terkecil berada pada jaringan IV di
Kecamatan Pinggir yaitu Rp 289,78/kg dari harga jual pabrik. Nilai farmer'share yang diperoleh dari jaringan IV di Kecamatan Pinggir yang paling banyak sebesar $78,21 \%$. Sementara, nilai terkecil diperoleh pada jaringan I di Kecamatan Bantan sebesar $46,43 \%$.

\section{DAFTAR PUSTAKA}

BPS Indonesia. 2020. Statistik kelapa sawit Indonesia 2019. Dilihat 15 Desember 2020. <https://www.bps.go.id/publication/20 20/11/30/36cba77a73179202def4ba14/st atistik-kelapa-sawit-indonesia-2019.html>

BPS Kabupaten Bengkalis. 2020. Kabupaten Bengkalis dalam Angka 2020. Dilihat $15 \quad$ Desember 2020. <https:// bengkaliskab.bps.go.id/publ ication/2020/02/28/6e7b6ce879002f07 d04d6f5c/kabupaten-bengkalis-dalamangka-2020--penyediaan-data-untukperencanaan-pembangunan.html>

BPS Riau. 2020. Provinsi Riau Dalam Angka 2020. Dilihat 15 Desember 2020. $<$ https://riau.bps.go.id/publication/202 0/04/27/a7d70bfbb3ce90b6b6a640d6/p rovinsi-riau-dalam-angka-2020.html>

Da Silva, CA, Baker, D, Shepherd, AW, Jenane, C, Miranda-da-Cruz, S. 2009. AgroIndustries for development. CABI. https://doi.org/10.1079/978184593576 4.0000

Dianto, -F., Efendi, -D., Wachjar, -A., 2017. Pengelolaan panen kelapa sawit (Elaeis guineensis Jacq.) pelantaran agro estate, kota Waringin Timur, Kalimantan Tengah. Buletin Agrohorti. 5, 410-417. https://doi.org/10.29244/agrob.v5i3.1 9574

Gunanegara. 2019. Hukum Perkebunan: Sejarah dan Latar belakangnya. PT. Adhi Sarana Nusantara, Jakarta

Jumiati, -E., Darwanto, D, -H., Hartono, -S., Masyhuri, 2013. Analisis saluran pemasaran dan marjin pemasaran kelapa dalam di daerah perbatasan Kalimantan Timur. Agrifor Jurnal Ilmu Pertanian dan Kehutanan. 12, 1-10. https://doi.org/10.31293/af.v12i1.165

Kotler, P. 2002. Manajemen Pemasaran: Analisis Perencanaan Implementasi dan Kontrol. Erlangga, Jakarta 
Kusumawati, A. 2013. Rantai Nilai (Value Chain) Agribisnis Labu di Kecamatan Getasan Kabupaten Semarang. Skripsi. Universitas Diponegoro. Semarang

Leppe, E, -P., Karuntu, -M., 2019. Analisis manajemen rantai pasokan industri rumahan tahu di kelurahan Bahu Manado. Jumal EMBA: Jurnal Riset Ekonomi Manajemen, Bisnis dan Akuntansi. 7, 201-210. https://doi.org/10.35794/emba.v7i1.2234 7

Lie, -H., Rich, K, -M., Kurwijila, L, -R., Jervell, A, -M., 2012. Improving smallholder livelihoods through local value chain development: A case study of goat milk yogurt in Tanzania. International Food and Agribusiness Management Review. 15, 55-86. https://doi.org/10.22004/ag.econ.132 789

Limbong, WH, Sitorus, P. 1987. Pengantar Tataniaga Pertanian. IPB. Bogor

Lubis, F, R, -A., Tinaprilla, -N., 2016. Sistem tataniaga tandan buah segar di kecamatan Wampu, Kabupaten Langkat, Sumatera Utara. Agrica, Jurnal Agribisnis Sumatera Utara. 4, 126-139. https://doi.org/10.31289/agrica.v9i2.5 45

Mulyana, -A., 2008. Penetapan harga tandan buah segar kelapa sawit di sumatera selatan dari perspektif pasar monopoli bilateral. SOCA Jurnal Sosial Ekonomi Pertanian. 8(2), 1-18. https://ojs.unud.ac.id/index.php/so $\mathrm{ca} /$ article/view/4184/3169

Mumbeya, NP. 2011. A value chain and Market Integration Analysis of the Cassava Market in the Democratic Republic of Congo. Thesis. University of Pretoria. Pretoria

Noor, D, -A., 2013. Analisis pemasaran tandan buah segar kelapa sawit di kecamatan long ikis kabupaten Paser. Jurnal Ekonomi Pertanian dan Pembangunan. 10, 35-42. http://agb.faperta.unmul.ac.id/wpcontent/uploads/2017/04/jurnal-vol10-no-1-dedy-adhan.pdf

Novida, A, Saleh, K, Saragih, F, H. 2020. Analisis efisiensi pemasaran kelapa sawit petani rakyat di desa prapat janji kecamatan Buntupane Kabupaten Asahan. Prosiding
Seminar Nasional Pangan dan Perkebunan: Realitas Pangan dan Perkebunan Saat Ini dan Prospeknya menuju Swasembada Berkelanjutan. Universitas Halu Oleo, Kendari, pp. 175-185

Phiri, L, -Y., Dzanja, -J., Kakota, -T., Hara, M., 2013. Value chain analysis of Lake Malawi Fish: A case study of Oreochromis spp (Chambo). International Journal Business and Social Science. 4, 170-181. https://citeseerx.ist.psu.edu/view doc/download?doi=10.1.1.827.4210 \&rep=rep $1 \&$ type $=$ pdf

Pratama, E. 2020. Analisis Pemasaran Tandan Buah Segar Kelapa Sawit Petani Swadaya di Desa Mekar Jadi Kecamatan Sungai Lilin Kabupaten Musi Banyuasin. Skripsi. Universitas Sriwijaya, Palembang

Pratama, G, -R., Hardjomidjojo, -H., Iskandar, -A., Muhandri, -T., 2018. Analisis rantai nilai agroindustri sagu di Kabupaten Kepulauan Meranti. Jurnal Teknologi Industri Pertanian. 28, 199-209. https://doi.org/10.24961/j.tek.ind.pert.2 018.28.2.199

Primalasari, -I., Sumantri, -B., Sriyoto, -S., 2017. Analisis rantai pasok tandan buah segar (TBS) Pada PT. Sandabi Indah Lestari di Kabupaten Bengkulu Utara. Jurnal AGRISEP: Kajian Masalah Sosial Ekonomi Pertanian dan Agribisnis. 16, 87-96. https://doi.org/10.31186/jagrisep. 16.1.87-96

Rasoki, -T., Fariyanti, -A., Rifin, -A., 2017. Pembandingan efisiensi pemasaran bawang merah konsumsi dan benih di Kabupaten Brebes, Provinsi Jawa Tengah. Jurnal Agro Ekonomi. 34, 145-160. https://doi.org/10.21082/jae.v34n2.2016 $.145-160$

Rothaermel, FT., 2017. Strategic Management. McGraw-Hill Education, USA

Saragih, AE., 2016. Rantai Pasok Beras di Kecamatan Cibeber, Kabupaten Cianjur. Tesis. IPB. Bogor

Syahza, -A., 2011. Percepatan ekonomi pedesaan melalui pembangunan perkebunan kelapa sawit. Jurnal Ekonomi Pembangunan. 12, 297-310. https://doi.org/10.23917/jep.v12i2.200 
Jurnal Teknologi Pertanian Vol. 22 No. 2 [Agustus 2021] 109-120

Analisis Value Chain dan Margin Pemasaran Rantai Pasok Tandan Buah Segar Sawit [Rahayu dkk]

Syibil, M. 2013. Analisis Rantai Nilai pada Komoditas Jamur Tiram Putih di Kabupaten Bogor (Studi Kasus Pada P4S Nusa Indah). Skripsi. IPB. Bogor

Tansala, S, -P., Gunawan, -S., Santosa, T, N, -B., 2017. Kajian efektivitas panen kelapa sawit menggunakan dodos modifikasi dan dodos biasa pada tm muda. Jurnal AGROMAST. 2, 67-73. http://36.82.106.238:8885/jurnal/index. php/JAI/article/view/412

Ugroseno, -R., Wachjar, -A., 2017. Manajemen pemanenan dan penanganan pasca panen kelapa sawit
(Elaeis guineensis Jacq.) di Teluk Siak Estate, Riau. Buletin Agrohorti. 5, 309-315. https://doi.org/10.29244/agrob.v5i3.16 468

Yulistriani, Paloma, -C., Hasnah., 2018. Analisis risiko pasca panen tandan buah segar (TBS) kelapa sawit di Kabupaten Dharmasraya. AGRIFO Jurnal Agribisnis Universitas Malikussaleh. 3, 45-56. https://doi.org/10.29103/ag.v3i1.676

Yuniar, AR. 2012. Analisis Manajemen Rantai Pasok Melon di Kabupaten Karanganyar. Tesis. Universitas Sebelas Maret. Surakarta 